\title{
GESTAÇÃO DE FETOS ANENCEFÁLICOS E PESQUISAS COM CÉLULAS-TRONCO: DOIS TEMAS ACERCA DA VIDA E DA DIGNIDADE NA CONSTITUIÇÃO ${ }^{1}$
}

\section{LUÍS ROBERTO BARROSO*}

I. Introdução. Parte I. ALGUNS ASPECTOS TÉCNICOS E CIENTÍFICOS. II. Anencefalia e interrupção da gestação. III. A importância das pesquisas com células-tronco. Parte II. A questão do ponto de vista ético. IV. O debate sobre o início da vida. Parte III. A questão do ponto de vista jurídico. $V$. Constitucionalidade e legitimidade da antecipação terapêutica do parto em caso de feto anencefálico. VI. Constitucionalidade e legitimidade das pesquisas com células-tronco embrionárias. Parte IV. A questão do ponto de vista institucional. VII. Centralidade da Constituição e constitucionalização do Direito. VIII. A jurisdição constitucional e sua legitimidade democrática. IX. A ADPF no 54 e a questão da atuação do Supremo Tribunal Federal como legislador positivo. X. A ADIn $n^{\circ} 3.510$ e os limites da atuação do Supremo Tribunal Federal como legislador negativo. Conclusão.

\section{Introdução}

A constitucionalização do Direito e a ascensão política e institucional do Poder Judiciário produziram um fenômeno singular no Brasil contemporâneo: a judicialização de questões políticas e sociais, que passaram a ter nos tribunais a sua instância

1 O presente texto serviu de base para exposição realizada na XIX Conferência Nacional da Ordem dos Advogados da Ordem dos Advogados do Brasil, realizada em Florianópolis, SC, de 25 a 29 de novembro de 2005 .

* Professor Titular de direito constitucional da Universidade do Estado do Rio de Janeiro - UERJ (graduação e pós-graduação). Mestre em Direito pela Universidade de Yale. Doutor Livre-docente pela UERJ. Conselheiro do Conselho de Defesa dos Direitos da Pessoa Humana. Advogado. 
decisória final. Assim tem ocorrido com temas envolvendo (i) políticas públicas, como as Reformas da Previdência e do Judiciário; (ii) relações entre Poderes, como na demarcação dos limites legítimos dos poderes das CPIs ou do papel do Ministério Público na investigação criminal; (iii) em questões do dia a dia, como as relativas à legalidade da cobrança de assinaturas telefônicas e à majoração do valor das passagens de transporte coletivo ou da mensalidade dos planos de saúde.

No plano dos direitos fundamentais, duas ações judiciais em curso perante o Supremo Tribunal Federal mobilizaram a opinião pública e a comunidade jurídica de uma maneira geral:

1. a Argüição de Descumprimento de Preceito Fundamental $n^{\circ} 54$, ajuizada pela Confederação Nacional dos Trabalhadores na Saúde, na qual se discute a legitimidade ou não da interrupção da gestação na hipótese de fetos anencefálicos. O pedido veiculado é a intepretação conforme a Constituição das normas do Código Penal referentes a aborto, para que seja declarada sua não incidência às hipóteses de antecipação terapêutica de parto em casos de gravidez de fato anencefálico; e

2. a Ação Direta de Inconstitucionalidade $n^{\circ} 3.510$, proposta pelo Procurador-Geral da República, na qual se discute a constitucionalidade ou não das normas da Lei $n^{\circ} 11.105$, de 24.03.2005 - Lei de Biossegurança -, que disciplinam as pesquisas com células-tronco embrionárias. O pedido veiculado na ação é o da declaração de inconstitucionalidade da íntegra do art. $5^{\circ}$ da Lei $^{2}$, para que sejam consideradas ilegítimas tais pesquisas.

Ambas as discussões são totalmente independentes. Nada obstante isto, além de terem sido alçadas ao Supremo Tribunal Federal em época contemporânea, existem diversas questões éticas e jurídicas que lhes são comuns, justificando o tratamento conjunto.

2 Assim dispõe o art. $5^{\circ}$ da Lei $n^{\circ} 11.105 / 2005:$ "Art. 5o. É permitida, para fins de pesquisa e terapia, a utilização de células-tronco embrionárias obtidas de embriões humanos produzidos por fertilização in vitro e não utilizados no respectivo procedimento, atendidas as seguintes condições: I - sejam embriões inviáveis; ou II - sejam embriões congelados há 3 (três) anos ou mais, na data da publicação desta Lei, ou que, já congelados na data da publicação desta Lei, depois de completarem 3 (três) anos, contados a partir da data de congelamento. $\S 1$ Em qualquer caso, é necessário o consentimento dos genitores. $\$ 2$ Instituições de pesquisa e serviços de saúde que realizem pesquisa ou terapia com células-tronco embrionárias humanas deverão submeter seus projetos à apreciação e aprovação dos respectivos comitês de ética em pesquisa. § $3^{2}$ É vedada a comercialização do material biológico a que se refere este artigo e sua prática implica o crime tipificado no art. 15 da Lei $n^{\circ} 9.434$, de 4 de fevereiro de 1997". 


\section{Parte I \\ ALGUNS ASPECTOS TÉCNICOS E CIENTÍFICOS}

\section{Anencefalia e interrupção da gestação}

A anencefalia é definida na literatura médica como a má-formação fetal congênita por defeito do fechamento do tubo neural durante a gestação, de modo que o feto não apresenta os hemisférios cerebrais e o córtex, havendo apenas resíduo do tronco encefálico ${ }^{3}$. Conhecida vulgarmente como "ausência de cérebro", a anomalia importa na inexistência de todas as funções superiores do sistema nervoso central responsável pela consciência, cognição, vida relacional, comunicação, afetividade e emotividade. Restam apenas algumas funções inferiores que controlam parcialmente a respiração, as funções vasomotoras e a medula espinhal ${ }^{4}$. Como é intuitivo, a anencefalia é incompatível com a vida extra-uterina, sendo fatal em $100 \%$ dos casos. Não há controvérsia sobre o tema na literatura científica ou na experiência médica.

Embora haja relatos esparsos sobre fetos anencefálicos que sobreviveram alguns dias fora do útero materno, o prognóstico nessas hipóteses é de sobrevida de no máximo algumas horas após o parto. Não há qualquer possibilidade de tratamento ou reversão do quadro, o que torna a morte inevitável e certa ${ }^{5}$. Aproximadamente $65 \%$ (sessenta e cinco por cento) dos fetos anencefálicos morrem ainda no período intra-uterino ${ }^{6}$.

O exame pré-natal mais comumente utilizado para detectar anomalias resultantes de má-formação fetal é a ecografia ${ }^{7}$. A partir do segundo trimestre de gestação, o procedimento é realizado através de uma sonda externa que permite um estudo morfológico preciso, incluindo-se a visualização, e.g., da caixa craniana do feto. No estado da técnica atual, o índice de falibilidade dessa espécie de exame é praticamente nulo, de modo que seu resultado é capaz de gerar confortável certeza médica.

Uma vez diagnosticada a anencefalia, não há nada que a ciência médica possa fazer quanto ao feto inviável. O mesmo, todavia, não ocorre com relação ao quadro clínico da gestante. A permanência do feto anômalo no útero da mãe é potencialmente perigosa, podendo gerar danos à saúde da gestante e até perigo de vida, em razão do alto índice de óbitos intra-útero desses fetos. De fato, a má-formação fetal em exame empresta à gravidez um caráter de risco, notadamente maior do que o inerente a uma gravidez normal ${ }^{8}$. Assim, a antecipação do parto nessa hipótese constitui

3 Richard E. Behrman, Robert M. Kliegman e Hal B. Jenson, Nelson/Tratado de pediatria, 2002. p. 1777.

4 Debora Diniz e Diaulas Costa Ribeiro, Aborto por anomalia fetal, 2003, p. 101.

5 Debora Diniz e Diaulas Costa Ribeiro, Aborto por anomalia fetal, 2003, p. 44.

6 Debora Diniz e Diaulas Costa Ribeiro, Aborto por anomalia fetal, 2003, p. 102.

7 V. definição constante do Dicionário enciclopédico de medicina (A. Céu Coutinho), p. 748: "Método auxiliar de diagnóstico baseado no registro gráfico de ecos de ultra-sons que são emitidos e captados por um aparelho especial que emite as ondas e capta os seus reflexos, fazendo também o seu registro gráfico (ecograma)." .

8 Em parecer sobre o assunto, a FEBRASGO - Federação Brasileira das Associações de Gine- 
indicação terapêutica médica: a única possível e eficaz para o tratamento da paciente (a gestante), já que para reverter a inviabilidade do feto não há solução.

\section{A importância das pesquisas com células-tronco}

A Lei $n^{\circ} 11.105 / 2005$ permite, para fins de pesquisa e terapia, a utilização de células-tronco obtidas de embriões humanos, produzidos mediante fertilização in vitro, e que não foram transferidos para o útero materno. Torna-se imprescindível, assim, percorrer algumas noções básicas acerca dessas técnicas.

A fertilização in vitro é um método de reprodução assistida, destinado em geral a superar a infertilidade conjugal, utilizado com sucesso desde $1978^{9}$. Ela permite que os espermatozóides fecundem os óvulos em laboratório, fora do corpo da mulher, quando este processo não possa ser realizado no seu lugar natural, que é a trompa de falópio. A prática médica consolidada é a de se retirarem diversos óvulos para serem fecundados simultaneamente, evitando-se a necessidade de submeter a mulher a sucessivos procedimentos de estimulação da ovulação e aspiração folicular a cada tentativa de fecundação e desenvolvimento do embrião.

Muitos dos embriões obtidos se revelam inviáveis. Quando, todavia, se realiza com êxito a fase de fecundação e desenvolvimento inicial, o embrião é transferido para o útero, onde deverá continuar seu ciclo de formação, até adquirir capacidade de implantação no endométrio, que é a camada interna do útero da mulher (nidação). As possibilidades de êxito na obtenção da gravidez aumentam em função do número de embriões transferidos. No entanto, para limitar os riscos da gravidez múltipla, a recomendação é a de transferência de dois embriões, sendo comum que se chegue a três. Os embriões excedentes são congelados ${ }^{10}$.

cologia e Obstetrícia atesta: "As complicações maternas são claras e evidentes. Deste modo, a prática obstetrícia nos tem mostrado que: A) A manutenção da gestação de feto anencefálico tende a se prolongar além de 40 semanas. B) Sua associação com polihidrâminio (aumento do volume no líquido amniótico) é muito freqüente. C) Associação com doença hipertensiva específica da gestação (DHEG). D) Associação com vasculopatia periférica de estase. E) Alterações do comportamento e psicológicas de grande monta para a gestante. F) Dificuldades obstétricas e complicações no desfecho do parto de anencéfalos de termo. G) Necessidade de apoio psicoterápico no pós-parto e no puerpério. H) Necessidade de registro de nascimento e sepultamento desses recém-nascidos, tendo o cônjuge que se dirigir a uma delegacia de polícia para registrar o óbito. I) Necessidade de bloqueio de lactação (suspender a amamentação). J) Puerpério com maior incidência de hemorragias maternas por falta de contratilidade uterina. K) Maior incidência de infecções pós-cirúrgicas devido às manobras obstetrícias do parto de termo."

9 O primeiro “bebê de proveta" do mundo, nascido em 05.07.98, foi Louise Joy Brown, que concretizou a possibilidade da concepção de um ser humano in vitro. V. Heloisa Helena Barboza, Proteção jurídica do embrião humano. In: Carlos Maria Romeo Casabona e Juliane Fernandes Queiroz, Biotecnologia e suas implicaçōes ético-jurídicas, 2005, p. 248.

10 Raquel de Lima Leite Soares Alvarenga, Considerações sobre o congelamento de embriōes. In: Carlos Maria Romeo Casabona e Juliane Fernandes Queiroz, Biotecnologia e suas implicações ético-jurídicas, 2005, p. 232 e ss.. 
As características que singularizam as células-tronco em relação às demais células são (a) a capacidade de se diferenciarem, i.e., de se converterem em distintos tecidos no organismo e (b) a propriedade de auto-replicação, ou seja, a capacidade que têm de produzirem cópias idênticas de si mesmas. Todavia, tais características não se manifestam com a mesma intensidade em todas as células-tronco. Estas podem ser classificadas em: (a) totipotentes, as quais possuem a capacidade de se diferenciar em qualquer dos 216 tecidos que compõem o corpo humano; $(b)$ pluripotentes ou multipotentes, que podem se diferenciar em quase todos os tecidos, menos na placenta e nos anexos embrionários; (c) oligopotentes, que são capazes de se diferenciar em poucos tecidos; ou (d) unipotentes, que só conseguem se diferenciar em um único tecido.

As totipotentes e as pluripotentes somente são encontradas nos embriões (por isso são chamadas de embrionárias). Tais células podem ser extraídas até três semanas após a fecundação (aproximadamente 14 dias) ${ }^{\mathrm{H}}$. É essa capacidade de se diferenciar em todas as células do organismo humano que faz com que as células-tronco embrionárias se tornem necessárias para a pesquisa médica ${ }^{12}$. Como as células-tronco adultas são apenas oligopotentes $^{13}$ ou unipotentes ${ }^{14}$, o seu potencial para a pesquisa é significativamente menor, embora também sejam dotadas de importância ${ }^{15}$.

Dentre as patologias cuja cura pode resultar das pesquisas com células embrionárias, podem ser citadas, por exemplo: as atrofias espinhais progressivas, as distrofias musculares, as ataxias, a esclerose lateral amiotrófica, a esclerose múltipla, as neuropatias e as doenças de neurônio motor, o diabetes, o mal de Parkinson, síndromes diversas (como as mucopolisacaridoses ou outros erros inatos do metabolismo etc.). Todas elas constituem doenças graves, que causam grande sofrimento a seus portadores. Tragicamente, estas patologias atingem parte considerável da população mundial. No Brasil, entre 10 a 15 milhões de pessoas têm diabetes ${ }^{16}$; 3\% a 5\% da população têm doenças genéticas que podem ser congênitas ou ter início na infância ou na idade adulta ${ }^{17}$; surgem entre 8.000 e 10.000 novos casos de lesão medular por ano (paraplegia ou tetraplegia) ${ }^{18}$.

11 Com a fecundação, tem origem um zigoto, formado por uma única célula. Esta se divide em duas, que se dividem em quatro, e assim ocorre sucessivamente até que se forme o feto. As células totipotentes são as que têm lugar nas primeiras fases desse processo contínuo de divisão celular (até o momento em que 16 células se dividem em 32), enquanto as pluripotentes somente surgem na fase de blastocisto (que se inicia quando as 32 células se dividem em 64). No blastocisto, as células internas são pluripotentes, enquanto as externas se destinam a produzir a placenta e as membranas embrionárias.

12 As outras duas características das células-tronco embrionárias que as tornam especialmente importantes para a pesquisa são a maior facilidade para isolá-las e a maior possibilidade de induzir o processo de diferenciação celular em laboratório. Sobre a importância das pesquisas com células-tronco embrionárias, v. Sell S. (editor), Stem Cells Handbook, 2004.

13 Esse é o caso, por exemplo, das células do trato intestinal.

14 Esse é o caso, por exemplo, das células do tecido cerebral adulto e da próstata.

15 Sell S. (editor), Stem Cells Handbook, 2004.

16 Fonte: Ministério da Saúde e Assoc. de Diabetes Juvenil.

17 Nardi, Doenças Genéticas: gênicas, cromossômicas, complexas, p. 209-226.

18 Fonte: Organização Mundial de Saúde. 
O debate de idéias nessa matéria pode se travar em diferentes níveis de abstração e complexidade, indo da fé à filosofia metafísica. Mas não pode desconsiderar o sofrimento real e concreto das pessoas portadoras dessas e de outras doenças, que precisam de solidariedade e empenho por parte do Estado, da sociedade e da comunidade científica.

\section{Parte II \\ A QUESTÃO DO PONTO DE VISTA ÉTICO}

\section{O debate sobre o início da vida}

Como se pretende demonstrar mais à frente, nem a interrupção da gestação de fetos anencefálicos nem a realização de pesquisas com células-tronco embrionárias violam o direito à vida e ou a dignidade humana. Antes pelo contrário. É preciso admitir, no entanto, que inexiste consenso científico ou filosófico acerca do momento em que tem início a vida. $O$ reconhecimento de uma linha divisória moralmente significativa entre óvulo fertilizado e pessoa humana é uma das grandes questões do debate ético contemporâneo. Há inúmeras concepções acerca do tema ${ }^{19}$.

Sem nenhuma pretensão de exaustividade, é possível enunciar algumas posições que têm sido defendidas no plano teórico, segundo as quais a vida humana se inicia: (i) com a fecundação; (ii) com a nidação ${ }^{20}$; (iii) quando o feto passa a ter capacidade de existir sem a mãe (entre a $24^{\mathrm{a}}$ e a $26^{\mathrm{a}}$ semanas da gestação) ${ }^{21}$; (iv) quando da formação do sistema nervoso central (SNC) ${ }^{22}$. Há até mesmo quem defenda que a vida humana se inicia quando passam a existir indicadores morais ${ }^{23}$. Não há necessidade nem conveniência de se prosseguir na enumeração das diferentes perspectivas debatidas no campo da bioética ${ }^{24}$. O ponto que se pretende aqui demonstrar é o da existência do que a filosofia moderna denomina de desacordo moral razoável ${ }^{25}$.

19 Para um inventário das diversas propostas, v. Tania Salem, As novas tecnologias reprodutivas: O estatuto do embrião e a noção de pessoa, Mana 3(I), 1997, p. 80. V. tb. Paul Singer, Vida ética, p. 186 e ss..

20 Essa posição lança mão do argumento de que só há potencial de vida quando o embrião se fixa no útero materno, já que o embrião não pode se desenvolver fora dele.

21 Deste critério se utilizam a Suprema Corte norte-americana, quando dispõe sobre o aborto, e o Comitê Nacional de Ética Francês, quando distingue entre "pessoa humana potencial" e "pessoa humana tout court".

22 O dado fundamental, para essa perspectiva, é a capacidade neurológica de sentir dor ou prazer.

23 Para os que depositam confiança nesta linha de pensamento, o que distingue a pessoa de todo o restante do mundo natural é a razão, a capacidade de fazer escolhas e a moral.

24 Aqui é pertinente a advertência de José Afonso da Silva, Curso de direito constitucional positivo, 2001, p. 200: "Nãe intentaremos dar uma definição disto que se chama vida, porque é aqui que se corre o grave risco de ingressar no campo da metafísica supra-real, que não nos levará a nada."

25 O desacordo moral razoável é aquele que tem lugar diante da ausência de consenso entre posições racionalmente defensáveis. Sobre o tema, v. Amy Gutmann e Dennis Thompson, Demo- 
Cumpre especular acerca da postura ética ideal em situações como esta. O senso moral de cada um envolve elementos diversos ${ }^{26}$, que incluem: a) a consciência de si, a definição dos próprios valores e da própria conduta; e b) a percepção do outro, o respeito pelos valores do próximo e a tolerância com sua conduta. Não se trata de pregar, naturalmente, um relativismo moral, mas de reconhecer a inadequação do dogmatismo onde a vida democrática exige pluralismo e diversidade. Em situações como essa, o papel do Estado deve ser o de assegurar o exercício da autonomia privada, de respeitar a valoração ética de cada um, sem a imposição externa de condutas imperativas.

É exatamente esta a tese defendida no presente estudo. Relativamente à antecipação terapêutica do parto, oferece-se à gestante a faculdade de não levar a termo a gestação inviável. No tocante às pesquisas com células-tronco, a Lei ${ }^{\circ} 11.105 / 2005$ exige, em qualquer caso, o "consentimento dos genitores" 27 . Após amplo debate, por deliberação majoritária expressiva, o Congresso Nacional assegurou o direito de cada um decidir, de acordo com seus valores pessoais. Como natural, também os médicos e pesquisadores irão decidir de maneira autônoma, de acordo com sua consciência.

Ainda em relação às pesquisas com células-tronco, deve-se assinalar que a Lei de Biossegurança vedou, de maneira inequívoca, linhas de atuação eticamente condenadas pela comunidade científica internacional. De fato, nela se proibiu, expressamente, a clonagem humana, punida com pena de reclusão e multa ${ }^{28}$. Também o risco da prática de eugenia é afastado, pela interdição e tipificação como crime da engenharia genética em seres humanos ${ }^{29}$. E, por fim, a lei neutralizou o temor de se criar um mercado de embriões e tecidos humanos - a "industrialização da vida" -, ao proibir e criminalizar a comercialização de material biológico ${ }^{30}$. O risco de transgressão existirá com ou sem regulamentação da matéria, mas a existência de lei tem a virtude de demarcar adequadamente a fronteira entre o lícito e o ilícito.

cracy and disagreement, 1997; Jeremy Waldron, Law and disagreement, 1999; John Rawls, Liberalismo político, 2000.

26 Sobre as condições a serem preenchidas pelo sujeito ético ou moral, v. Marilena Chaú, Convite à filosofia, 1999, p. 337 e ss..

27 Rememore-se a letra expressa do $\S 1^{\circ}$ do art. $5^{\circ}$ da Lei: "Em qualquer caso, é necessário o consentimento dos genitores"

28 Lei $\mathrm{n}^{\circ}$ 11.105/2005: Art. 60: "Fica proibido: (...) IV - clonagem humana;". Art. 26: "Realizar clonagem humana: Pena - reclusão, de 2 (dois) a 5 (cinco) anos, e multa".

29 Lei $n^{\circ} 11.105 / 2005$ : "Art. $6^{\circ}$. Fica proibido: (...) III - engenharia genética em célula germinal humana, zigoto humano e embrião humano". "Art. 25. Praticar engenharia genética em célula germinal humana ou embrião humano: Pena - reclusão, de 1 (um) a 4 (quatro) anos, e multa".

30 Lei $n^{\circ} 11.105 / 05$, art. $5^{\circ}, \S 3^{\circ}$ : É vedada a comercialização do material biológico a que se refere este artigo e sua prática implica o crime tipificado no art. 15 da Lei $n^{\circ} 9.434$, de 4 de fevereiro de 1997". Lei 9.434/97, art. 15: “Comprar ou vender tecidos, 6rgãos ou partes do corpo humano: Pena - reclusão, de três a oito anos, e multa, de 200 a 360 dias-multa. Parágrafo único. Incorre na mesma pena quem promove, intermedeia, facilita ou aufere qualquer vantagem com a transação". A comercialização de embriões já era vedada pela Resolução n. 1.358/92, do Conselho Federal de Medicina, que determinava em IV(1): “A doação [de gametas ou de pré-embrið̄es] nunca terá caráter lucrativo ou comercial." 


\section{Parte III \\ A QUESTÃO DO PONTO DE VISTA JURÍDICO}

\section{Constitucionalidade e legitimidade da antecipação terapêutica do parto em caso de feto anencefálico}

No Brasil, como em outras partes do mundo, é recorrente o debate acerca da questão do aborto e de sua criminalização, com a torrente de opiniões polarizadas que costuma acompanhá-lo. O Código Penal de 1940, como se sabe, tipificou o aborto na categoria dos crimes contra a vida. Esta visão, nos dias atuais, está longe de ser pacífica. A diversidade de concepções acerca do momento em que tem início a vida tem alçado este tema à deliberação de parlamentos e cortes constitucionais de diversos países, como Estados Unidos ${ }^{31}$, Canada ${ }^{32}$, Portugal $^{33}$, Espanha $^{34}$, França $^{35}$ e Alemanha ${ }^{36}$, dentre outros.

No presente estudo, todavia, passa-se ao largo dessa relevante discussão, com todas as suas implicações filosóficas, religiosas e sociais. A argumentação desen-

31 Roe v. Wade, 410 U.S. 113 (1973) e, mais recentemente, Planned Parenthood of Southwestern Pennsylvania v. Casey 505 U.S. 833 (1992). Nos Estados Unidos, reconhece-se à mulher o direito constitucional amplo para realizar aborto no primeiro trimestre de gravidez. Em relação ao segundo e ao terceiro trimestres, as restrições instituídas por leis estaduais podem ser progressivamente mais severas.

32 Morgentaler Smoling and Scott v. The Queen (1988). No julgamento desse caso, a Suprema Corte canadense reconheceu às mulheres o direito fundamental à prática do aborto. Esta nota e as quatro subsequientes beneficiam-se de pesquisa desenvolvida pelo Doutor e Procurador da República Daniel Sarmento, gentilmente cedida ao autor do presente artigo.

33 O Tribunal Constitucional português reconheceu a constitucionalidade de lei que permitia o aborto em circunstâncias específicas, dentre elas o risco à saúde física ou psíquica da gestante, feto com doença grave e incurável, gravidez resultante de estupro e outras situações de estado de necessidade da gestante (Acórdão 25/84).

34 A Corte Constitucional espanhola considerou inconstitucional lei que autorizava o aborto em casos de estupro, anomalias do feto e riscos à saúde física e mental da mãe porque a lei não exigia prévio diagnóstico médico nos casos de má-formação fetal e risco à saúde da gestante.

35 Em 1975, foi editada lei francesa permitindo o aborto, a pedido da mulher, até a $10^{\circ}$ semana de gestação, quando a gestante afirmasse que a gravidez lhe causa angústia grave, ou a qualquer momento, por motivos terapêuticos. A norma foi submetida ao controle de constitucionalidade (antes de editada) e ao controle de convencionalidade (após sua edição), tendo sido considerada compatível tanto com a Constituição francesa quanto com a Convenção Européia dos Direitos Humanos. Hoje, outra norma cuida da matéria, mantendo a possibilidade relativamente ampla de aborto na França.

36 Na Alemanha, após uma posição inicial restritiva, materializada na decisão conhecida como “Aborto I" (1975), a Corte Constitucional, em decisão referida como "Aborto II" (1993), entendeu que uma lei que proibisse em regra o aborto, sem criminalizar a conduta da gestante, seria válida, desde que adotasse outras medidas para proteção do feto. Registrou, contudo, que o direito do feto à vida, embora tenha valor elevado, não se estende a ponto de eliminar todos os direitos fundamentais da gestante, havendo casos em que deve ser permitida a realização do aborto. 
volvida, portanto, não questiona o tratamento dado ao aborto pelo direito positivo brasileiro em vigor, opção metodológica que não deve ser compreendida como concordância ou tomada de posição na matéria. É que, a rigor, a hipótese aqui tratada é muito mais simples. A antecipação terapêutica do parto de fetos anencefálicos situa-se no domínio da medicina e do senso comum, sem suscitar quaisquer das escolhas morais envolvidas na interrupção voluntária da gravidez viável ${ }^{37}$.

\section{V.1. Antecipação terapêutica do parto não é aborto. Atipicidade da conduta}

O aborto é descrito pela doutrina especializada como "a interrupção da gravidez com a consequiente morte do feto (produto da concepção)" ${ }^{38}$. Vale dizer: a morte deve ser resultado direto dos meios abortivos, sendo imprescindível tanto a comprovação da relação causal como a potencialidade de vida extra-uterina do feto. Não é o que ocorre na antecipação do parto de um feto anencefálico. Com efeito, a morte do feto nesses casos decorre da má-formação congênita, sendo certa e inevitável ainda que decorridos os nove meses normais de gestação. Falta à hipótese o suporte fático exigido pelo tipo penal.

Essa linha de entendimento decorre, de maneira inexorável, do próprio conceito jurídico de morte adotado no Direito brasileiro. De fato, a Lei ${ }^{\circ} 9.347$, de 4.02.97, permite a retirada de órgãos destinados a transplante após o diagnóstico de "morte encefálica" do doador ${ }^{39}$. Portanto, o indivíduo é considerado morto quando o seu cérebro deixa de ter atividade. Ora bem: o feto anencefálico sequer chega a ter início de atividade cerebral, pois não apresenta os hemisférios cerebrais e o córtex, havendo apenas resíduo do tronco encefálico. Tragicamente, não chega a tornar-se um ser vivo, em sentido técnico ${ }^{40}$.

A interrupção da gestação, nessa hipótese, é fato atípico. Em nome do princípio geral da legalidade e do princípio específico da reserva penal, não pode ser vedado ou punido.

37 Inexiste qualquer proximidade entre a pretensão aqui veiculada e o denominado aborto eugênico, cujo fundamento é eventual deficiência grave de que seja o feto portador. Nessa última hipótese, pressupõe-se a viabilidade da vida extra-uterina do ser nascido, o que não é o caso em relação à anencefalia.

38 Damásio E. de Jesus, Código Penal Anotado, 2002, p. 424.

39 Assim prevê a Lei ${ }^{\circ} 9.347$, de 4.02.97, que dispõe sobre a remoção de órgãos, tecidos e partes do corpo humano para fins de transplante e tratamento: "Art. $3^{\circ}$. A retirada post mortem de tecidos, órgãos ou partes do corpo humano destinados a transplante ou tratamento deverá ser precedida de diagnóstico de morte encefálica, constatada por dois médicos não participantes das equipes de remoção e transplante, mediante a utilização de critérios clínicos e tecnológicos definidos por resolução do Conselho Federal de Medicina".

40 Esta valoração é estritamente jurídica e não inibe uma compreensão diversão no plano espiritual ou religioso. 
Como se pretendeu demonstrar acima, a antecipação terapêutica do parto, quando se trate de feto anencefálico, não configura aborto. Todavia, ainda que assim se quisesse qualificá-la, não deveria ser punida, pelas razões a seguir expostas. $O$ Código Penal tipifica o aborto provocado pela gestante ou por terceiro nos arts. 124 a $126^{41}$. Mas não pune o aborto dito necessário, se não há outro meio de salvar a vida da gestante, nem tampouco o aborto desejado pela mulher, em caso de gravidez resultante de estupro ${ }^{42}$. Pois bem: a hipótese aqui em exame só não foi expressamente abrigada no art. 128 do Código Penal como excludente de punibilidade porque em 1940, quando editada sua Parte Especial, a tecnologia existente não possibilitava o diagnóstico preciso de anomalias fetais incompatíveis com a vida. Não é difícil demonstrar o ponto.

O Código Penal exclui a punibilidade do aborto no caso de gravidez decorrente de estupro. Na sua valoração de fatores como a potencialidade de vida do feto e o sofrimento da mãe, vítima de uma violência, o legislador fez uma ponderação moral e permitiu a cessação da gestação. No caso aqui estudado, a ponderação é mais simples e envolve escolha moral menos drástica: o imenso sofrimento da mãe, de um lado, e a ausência de potencialidade de vida, do outro lado. Parece claro que o Código Penal, havendo autorizado o mais, somente não fez referência ao menos porque não era possível vislumbrar esta possibilidade no momento em que foi elaborado.

Deve-se aplicar aqui, no entanto, uma interpretação evolutiva do Direito. A norma jurídica, uma vez posta em vigor, liberta-se da vontade subjetiva que a criou e passa a ter uma existência objetiva e autônoma. É isso que permite sua adaptação a novas situações, ainda que não antecipadas pelo legislador, mas compreendidas na ordem de valores que o inspirou e nas possibilidades e limites oferecidos pelo texto normativo. Afigura-se fora de dúvida que a antecipação de parto aqui defendida situa-se no âmbito lógico das excludentes de punibilidade criadas pelo Código, por ser muito menos grave do que a que vale para o aborto em caso de estupro.

41 Código Penal: "Aborto provocado pela gestante ou com seu consentimento. Art. 124. Provocar aborto em si mesma ou consentir que outrem lho provoque: Pena - detenção, de 1 (um) a 3 (três) anos. Aborto provocado por terceiro. Art. 125. Provocar aborto, sem o consentimento da gestante: Pena - reclusão, de 3 (três) a 10 (dez) anos. Art. 126. Provocar aborto com o consentimento da gestante: Pena - reclusão, de 1 (um) a 4 (quatro) anos”.

42 Código Penal: "Art. 128. Não se pune o aborto praticado por médico: Aborto necessário. $I$ se não há outro meio de salvar a vida da gestante; Aborto no caso de gravidez resultante de estupro. $I I$ - se a gravidez resulta de estupro e o aborto é precedido de consentimento da gestante ou, quando incapaz, de seu representante legal." 


\section{V.3. Dignidade da pessoa humana, analogia à tortura e interpretação conforme a Constituição}

A dignidade da pessoa humana foi alçada ao centro dos sistemas jurídicos contemporâneos. A banalização do $\mathrm{mal}^{43}$ ao longo da primeira metade do século $\mathrm{XX}$ e a constatação, sobretudo após as experiências do fascismo e do nazismo, de que a legalidade formal poderia encobrir a barbárie levaram à superação do positivismo estrito e ao desenvolvimento de uma dogmática principialista, também identificada como pós-positivismo ${ }^{44}$. Nesse novo paradigma, dá-se a reaproximação entre o Direito e a Ética, resgatam-se os valores civilizatórios, reconhece-se normatividade aos princípios e cultivam-se os direitos fundamentais. Sob este pano de fundo, a Constituição de 1988 consagrou a dignidade da pessoa humana como fundamento do Estado democrático de direito (art. $1^{\circ}$. III) ${ }^{45}$.

O princípio da dignidade da pessoa humana identifica um espaço de integridade moral a ser assegurado a todas as pessoas por sua só existência no mundo. Relaciona-se tanto com a liberdade e valores do espírito quanto com as condições materiais de subsistência. Aliás, o reconhecimento dos direitos da personalidade como direitos autônomos ${ }^{46}$, de que todo indivíduo é titular ${ }^{47}$, generalizou-se também após a Segunda Guerra Mundial e a doutrina descreve-os hoje como emanações da própria dignidade, funcionando como "atributos inerentes e indispensáveis ao ser humano" ${ }^{48}$. Tais direitos, reconhecidos a todo ser humano ${ }^{49}$ e consagrados pelos textos

43 A expressão foi empregada por Hannah Arendt em Eichmann em Jerusalém - um relato sobre a banalidade do mal, trad. José Rubens Siqueira, Companhia das Letras, 1999.

44 V. Paulo Bonavides, Curso de direito constitucional, 1999, p. 237. Sobre o tema, na doutrina nacional, v. tb. Luís Roberto Barroso, "Fundamentos teóricos e filosóficos do novo direito constitucional brasileiro (Pós-modernidade, teoria crítica e pós-positivismo)". In: A nova interpretação constitucional: ponderação, direitos fundamentais e relações privadas, 2003.

45 Alguns trabalhos monográficos recentes sobre o tema: José Afonso da Silva, Dignidade da pessoa humana como valor supremo da democracia, Revista de Direito Administrativo 212/89; Cármen Lúcia Antunes Rocha, $O$ princípio da dignidade da pessoa humana e a exclusão social, Anais da XVII Conferência Nacional da Ordem dos Advogados do Brasil, 1999; Ingo Wolfgang Sarlet, Dignidade da pessoa humana e direitos fundamentais na Constituição brasileira de 1988 , 2001; Cleber Francisco Alves, O principio constitucional da dignidade da pessoa humana, 2001; Ana Paula de Barcellos, A eficácia jurídica dos princípios constitucionais. O princípio da dignidade da pessoa humana, 2001.

46 Sobre a discussão acerca da existência autônoma dos direitos da personalidade, v. Pietro Perlingieri, Perfis do direito civil, 1997, p. 155.

47 Pietro Perlingieri, La personalità umana nell'ordenamento giuridico, apud Gustavo Tepedino, "A tutela da personalidade no ordenamento civil-constitucional brasileiro". In: Temas de direito civil, 2001, p. 42: " $O$ direito da personalidade nasce imediatamente e contextualmente com a pessoa (direitos inatos). Está-se diante do princípio da igualdade: todos nascem com a mesma titularidade e com as mesmas situações juridicas subjetivas (...) A personalidade comporta imediata titularidade de relações personalíssimas."

48 Gustavo Tepedino, "A tutela da personalidade no ordenamento civil-constitucional brasileiro". In: Temas de direito civil, 2001, p. 33.

49 Mônica Neves Aguiar da Silva Castro, Honra, imagem, vida privada e intimidade, em colisão 
constitucionais modernos em geral, são oponíveis a toda a coletividade e também ao Estado ${ }^{50}$.

Uma classificação que se tornou corrente na doutrina é a que separa os direitos da personalidade, inerentes à dignidade humana, em dois grupos: (i) direitos à integridade física, englobando o direito à vida, o direito ao próprio corpo e o direito ao cadáver; e (ii) direitos à integridade moral, rubrica na qual se inserem os direitos à honra, à liberdade, à vida privada, à intimidade, à imagem, ao nome e o direito moral do autor, dentre outros.

A relevância desses direitos para a hipótese aqui em discussão é simples de ser demonstrada. Impor à mulher o dever de carregar por nove meses um feto que sabe, com plenitude de certeza, não sobreviverá, causando-lhe dor, angústia e frustração, importa violação de ambas as vertentes de sua dignidade humana. A potencial ameaça à integridade física e os danos à integridade moral e psicológica na hipótese são evidentes. A convivência diuturna com a triste realidade e a lembrança ininterrupta do feto dentro de seu corpo, que nunca poderá se tornar um ser vivo, podem ser comparadas à tortura psicológica. A Constituição Federal, como se sabe, veda toda forma de tortura (art. 5, III) e a legislação infra-constitucional define a tortura como situação de intenso sofrimento físico ou mental ${ }^{51}$

A hipótese, portanto, é de leitura dos dispositivos do Código Penal à luz da Constituição, para excluir sua incidência no caso de antecipação de parto de fetos anencefálicos. A técnica da interpretação conforme a Constituição, desenvolvida pela doutrina moderna ${ }^{52}$ e amplamente acolhida pelo Supremo Tribunal Federal ${ }^{53}$,

com outros direitos, 2002, p. 67: "Identificados como inatos, no sentido de que não é necessária a prática de ato de aquisição, posto que inerentes ao homem, bastando o nascimento com vida para que passem a existir, os direito da personalidade vêm sendo reconhecidos igualmente aos nascituros."

50 Miguel Ángel Alegre Martínez, El derecho a la propia imagen, 1997, p. 140: "Es de notar, además, que los destinatarios de esse deber genérico son todas las personas. El respeto a los derechos fundamentales, traducción del respeto a la dignidad de la persona, corresponde a todos, precisamente porque los derechos que deben ser respetados son patrimonio de todos, y el no respeto a los mismos por parte de cualquiera privará al otro del disfrute de sus derechos, exigido por su dignidad."

51 Lei $n^{\circ}$ 9.455, de 7.04.1997: "Art $1^{\circ}$ Constitui crime de tortura: I - constranger alguém com emprego de violência ou grave ameaça, causando-lhe sofrimento físico ou mental: a) com o fim de obter informação, declaração ou confissão da vítima ou de terceira pessoa; b) para provocar ação ou omissão de natureza criminosa; c) em razão de discriminação racial ou religiosa; II — submeter alguém, sob sua guarda, poder ou autoridade, com emprego de violência ou grave ameaça, a intenso sofrimento físico ou mental, como forma de aplicar castigo pessoal ou medida de caráter preventivo." (acrescente-se: causada intencionalmente ou que possa ser evitada).

52 O princípio da interpretação conforme a Constituição tem sua trajetória e especialmente o seu desenvolvimento recente ligados à jurisprudência do Tribunal Constitucional Federal alemão, onde sua importância é crescente. V. Honrad Hesse, La interpretación constitucional, in Escritos de derecho constitucional, 1983, p. 53. V. tb., dentre muitos outros, Jorge Miranda, Manual de direito constitucional, 1983, t. 2., p. 232 e ss; Gilmar Ferreira Mendes, Controle de constitucionalidade, 1990, p. 284 e ss.; Eduardo García de Enterria, La Constituición como norma y el Tribunal Constitucional, 1991, p. 95; J.J. Gomes Canotilho, Direito constitucional, 1991, p. 236.

53 V. sobre o tema, ilustrativamente, STF, Cadernos de Direito Constitucional e Ciência Política 1:314, Rep. 1.417-7, Rel. Min. Moreira Alves. No mesmo sentido: RTJ 139/624; RTJ 144/146. 
consiste na escolha de uma linha de interpretação para determinada norma legal, em meio a outras que o texto comportaria. Por essa via, dá-se a expressa exclusão de um dos sentidos possíveis da norma, por produzir um resultado que contravém a Constituição, e a afirmação de outro sentido, compatível com a Lei Maior, dentro dos limites e possibilidades oferecidos pelo texto.

Por todos esses fundamentos, o pedido veiculado na ADPF $\mathrm{n}^{\circ} 54$ foi no sentido de que se procedesse à interpretação conforme a Constituição dos arts. 124, $126 \mathrm{e}$ 128, I e II, do Código Penal para declarar "inconstitucional, com eficácia erga omnes e efeito vinculante, a interpretação de tais dispositivos como impeditivos da antecipação terapêutica do parto em casos de gravidez de feto anencefálico, diagnosticados por médico habilitado, reconhecendo-se o direito subjetivo da gestante de se submeter a tal procedimento, sem a necessidade de apresentação prévia de autorização judicial ou qualquer outra forma de permissão específica do Estado".

\section{Constitucionalidade e legitimidade das pesquisas com células-tronco embrionárias}

A tese central na qual se baseia a objeção às pesquisas com células-tronco é a de que "a vida humana acontece na, e a partir da fecundação". É este o fundamento da ADIn $n^{\circ} 3.510$, na qual o Procurador-Geral da República alega que os dispositivos legais impugnados violariam dois preceitos da Constituição da República: o art. $5^{\circ}$, caput, que consagra o direito à vida; e o art. $1^{\circ}$, III, que enuncia como um dos fundamentos do Estado brasileiro o princípio da dignidade da pessoa humana. Os argumentos desenvolvidos na ação podem ser resumidos em uma proposição: o embrião é um ser humano cuja vida e dignidade seriam violadas pela realização das pesquisas que as disposições legais impugnadas autorizam.

Antes de prosseguir, cumpre expor, de maneira objetiva, o sistema introduzido pela Lei $n^{\circ} 11.105 / 2005$, em sua unidade e harmonia. A Lei permite a realização de pesquisas com células extraídas de embriões, mas exige que: a) os embriões tenham resultado de tratamentos de fertilização in vitro (art. $5^{\circ}$, caput); b) os embriões sejam inviáveis (art. $\left.5^{\circ}, \mathrm{I}\right)$ ou que não tenham sido implantados no respectivo procedimento de fertilização, estando congelados há mais de três anos (art. $\left.5^{\circ}, \mathrm{II}\right) ; \mathrm{c}$ ) os genitores dêem seu consentimento (art. $5^{\circ}, \S 1^{\circ}$ ); d) a pesquisa seja aprovada pelo comitê de ética da instituição (art. $5^{\circ}, \S 2^{\circ}$ ). Por outro lado, a Lei proíbe: a) a comercialização de embriões, células ou tecidos (art. $5^{\circ}, \S 3^{\circ}$, e Lei $n^{\circ} 9.434 / 97$, art. 15$)^{54}$; b) a clonagem humana (art. $\left.6^{\circ}, \mathrm{IV}\right)^{55}$; e c) a engenharia genética em célula germinal humana, zigoto humano e embrião humano (art. $6^{\circ}$, III $)^{56}$.

54 Lei $n^{\circ}$ 9.434/97: “Art. 15. Comprar ou vender tecidos, órgãos ou partes do corpo humano: Pena - reclusão, de três a oito anos, e multa, de 200 a 360 dias-multa. Parágrafo único. Incorre na mesma pena quem promove, intermedeia, facilita ou aufere qualquer vantagem com a transação". 5s Lei $n^{\circ} 11.105 / 2005:$ "Art. $6^{\circ}$. Fica proibido: (...) IV-clonagem humana". A clonagem humana pode ser reprodutiva ou terapêutica. Na clonagem reprodutiva, transfere-se o núcleo de uma célula 
O ponto de vista contrário às pesquisas com células-tronco embrionárias é respeitável, como são as múltiplas visões de mundo em uma sociedade pluralista, e deve ser enfrentado com seriedade científica e filosófica. É o que se pretende fazer no presente estudo, no qual se percorrerão os argumentos jurídicos e biológicos que infirmam a tese na qual se baseia a oposição ao desenvolvimento de tais pesquisas. Será demonstrado, também, que a disciplina da matéria pela legislação atacada caracteriza-se pela prudência e pela moderação e que, em lugar de violar a vida e a dignidade humana, o tratamento dado ao tema promove esses valores de maneira adequada.

\section{VI.1. Bioética, biodireito e Constituição}

O Direito e a Ética desenvolveram, nas últimas décadas, uma trajetória de aproximação. Superando a separação ideológica que fora imposta pelo positivismo jurídico, renovou-se a relação entre o sistema de normas e o sistema de valores da sociedade. Esta virada kantiana ${ }^{57}$ abriu caminho para a filosofia do direito da quadra atual, identificada como pós-positivismo ${ }^{58}$. Direito e Ética enfrentam os desafios dos avanços tecnológicos e das ciências biológicas, que deram ao homem o poder de interferir em processos antes privativos da natureza.

adulta para um óvulo, do qual se retirou o núcleo. Esta célula começa a se replicar dando origem a um embrião, o qual, implantado em um útero, pode se desenvolver gerando um ser geneticamente idêntico ao doador. Na clonagem terapêutica, o processo é o mesmo até a formação do embrião. Quando este se forma, são extraídas células-tronco, que, cultivadas, podem constituir um tecido capaz de ser transplantado para o doador. A grande vantagem dessa técnica é evitar a rejeição, se as células-tronco forem reintroduzidas na mesma pessoa que doou o núcleo da célula adulta. Sobre o tema, v. Mayana Zatz, Clonagem humana: contras e prós, Parcerias Estratégicas 16:133, 2002. 56 Lei $n^{\circ}$ 11.105/2005: "Art. $6^{\circ}$. Fica proibido: (...) III - engenharia genética em célula germinal humana, zigoto humano e embrião humano".

57 A expressão se deve à influência do pensamento de Kant e às duas formulações do imperativo categórico, proposições éticas superadoras do utilitarismo: a) uma pessoa deve agir como se a máxima da sua conduta pudesse se transformar em uma lei universal; b) cada indivíduo deve ser tratado como um fím em si mesmo, e não como um meio para realização de metas coletivas ou de outras metas individuais. V. Immanuel Kant, Fundamentación de la metafísica de las costumbres, 1951. V. tb. Ted Honderich (editor), The Oxford companion to Philosophy, 1995, p. 589; Ricardo Lobo Torres, Tratado de direito constitucional financeiro e tributário: Valores e princípios constitucionais tributários, 2005: e Ricardo Terra, Kant e o direito, 2005.

58 A expressão pós-positivismo abriga um conjunto difuso de idéias, que incluem a volta dos valores ao Direito, a formulação de uma teoria da justiça e o desenvolvimento de uma teoria dos direitos fundamentais, edificada sobre o fundamento da dignidade humana. Autores pioneiros nesse debate foram: John Rawls, A theory of justice, 1971; Ronald Dworkin, Taking rights seriously, 1977; Roben Alexy, Teoria de los derechos fundamentales, 1993; Paulo Bonavides, Curso de direito constitucional, 2004. V. Albert Calsamiglia, Postpositivismo, Doxa 21:209, 1998, p. 209: "Denominaré postpositivistas a las teorías contemporáneas que ponen el acento en los problemas de la indeterminación del derecho y las relaciones entre el derecho, la moral y la política". 
O biodireito é um subsistema jurídico em desenvolvimento acelerado, voltado para o estudo e disciplina dos fenômenos resultantes da biotecnologia e da biomedicina, como a reprodução assistida, a clonagem terapêutica e reprodutiva, a mudança de sexo, as pesquisas com células-tronco embrionárias. A Lei n $n^{\circ} 11.105 / 2005$ representa um esforço meritório de trazer a justiça, a segurança jurídica e a busca pelo bem-estar social para este domínio. A bioética, por sua vez, tem por objeto a demarcação das possibilidades e limites dos progressos científicos nesses domínios, à luz da filosofia moral, dos valores a serem preservados por cada sociedade e pela humanidade em geral ${ }^{59}$. Os princípios éticos básicos da pesquisa científica são (i) a autonomia, (ii) a beneficência e (iii) a justiça ${ }^{60}$.

O encontro ente o Direito e a Ética se dá, em primeiro lugar, na Constituição, onde os valores morais se convertem em princípios jurídicos. A partir daí se irradiam pelo sistema normativo, condicionando a interpretação e a aplicação de todo o direito infraconstitucional $^{61}$. As leis editadas pelo Congresso Nacional, por sua vez, expressam a vontade majoritária da sociedade em relação à disciplina da matéria que contêm. Cabe ao Supremo Tribunal Federal o papel relevante e delicado de encontrar o ponto de equilíbrio entre (i) a determinação de sentido dos valores inscritos na Constituição e o (ii) respeito ao processo político majoritário.

Expostos os conceitos técnicos e doutrinários subjacentes à discussão aqui empreendida, passa-se à demonstração de duas teses: a inexistência da violação do direito à vida $\mathrm{e}$ a inexistência de violação ao princípio da dignidade humana.

\section{VI.2. Inexistência de violação do direito à vida}

O argumento contrário à utilização de células-tronco em pesquisas e tratamentos médicos é alimentado, no mais das vezes, por um sentimento religioso. Funda-se ele

59 Sobre esta temática. v. Heloisa Helena Barbosa e Vicente de Paulo Barreto (orgs.), Temas de biodireito e bioética, 2001 e, dos mesmos autores e também Jussara M.L. de Meirelles, Novos temas de biodireito e bioética, 2003.

60 Na sequiência do Tribunal de Nuremberg foi elaborado o Código de Nuremberg (1947), estabelecendo padrões éticos para a experimentação com seres humanos. Sucedeu-o a Declaração de Helsinki, aprovada pela Assembléia Médica Mundial em 1964, contendo "recomendações para orientar os médicos na investigação biomédica em seres humanos". E, por fim, foi elaborado o Relatório Belmont, de 1978, redigido por uma comissão do Congresso norte-americano. Nele foram Jançados os princípios da bioética. O princípio da autonomia ou do respeito pelas pessoas envolve dois requisitos morais distintos: o de reconhecer a livre-determinação de cada pessoa e o de proteger aqueles que possuem autonomia reduzida. O princípio da beneficência se expressa em duas regras complementares: a) não causar dano e b) maximizar benefícios. O princípio da justiça envolve a questão complexa de se determinar quem deve receber os benefícios da pesquisa e quem deve financiar seus custos. Sobre o tema, inclusive com a versão traduzida para o português do Relatório Belmont, v. Darlei Dall'Agnol, Bioética, 2005.

61 Sobre o tema, v. Luís Roberto Barroso, Neoconstitucionalismo e constitucionalização do Direito, Revista de Direito Administrativo 240, 2005, p. 1 e ss.. 
no pressuposto de que a vida teria início com a fecundação, fazendo a equiparação entre embrião e pessoa humana ${ }^{62}$. Como consequiência, sua destruição para a realização de pesquisas e para o tratamento de outras pessoas representaria uma violação da vida. Não se deve, em nenhuma hipótese, desmerecer a crença sincera de qualquer pessoa ou doutrina ${ }^{63}$. Mas no espaço público de um Estado laico hão de prevalecer as razões do Direito e da Ciência.

A Constituição da República assegura a inviolabilidade do direito à vida (art. $5^{\circ}$, caput). O Código Civil de 2002, reproduzindo normas do Código de 1916, assim dispôs:

\section{"Art. 1". Toda pessoa é capaz de direitos e deveres na ordem civil".}

"Art. 2". A personalidade civil da pessoa começa do nascimento com vida; mas a lei põe a salvo, desde a concepção, os direitos do nascituro".

Portanto, é a partir do nascimento com vida que surge a pessoa humana, com aptidão para tornar-se sujeito de direitos e deveres. Nada obstante, a lei resguarda, desde a concepção, os direitos do nascituro. Semanticamente, nascituro é o ser humano já concebido, cujo nascimento se espera como fato certo ${ }^{64}$. Os civilistas chamam a atenção, no entanto, para o fato de que este ser deverá estar em desen-

62 Essa é a posição defendida pela Congregazione per la Dottrina della Fede. No documento intitulado Il rispetto della vita umana nascente e la dignità della procreazione, de 1987, tal posição é afirmada: "Assim, o fruto da geração humana, a partir do primeiro momento de sua existência, isto é, a partir do momento em que o zigoto é formado, exige o respeito incondicional que é moralmente devido ao ser humano em sua totalidade corporal e espiritual. O ser humano deve ser respeitado e tratado como uma pessoa a partir do momento da concepção; e então, a partir do mesmo momento, seus direitos como uma pessoa devem ser reconhecidos, dentre os quais, em primeiro lugar, o direito inviolável de todo ser humano inocente à vida. Esta lembrança doutrinária provê o critério fundamental para a solução de vários problemas levantados pelo desenvolvimento das ciências biomédicas neste campo: como o embrião deve ser tratado como uma pessoa, deve também ser defendido em sua integridade, cuidado e protegido, à máxima extensão possível, da mesma forma que qualquer outro ser humano no que se refere à assistência médica". Após fixar esse critério geral, a Congregação se pronuncia especificamente acerca da impossibilidade da experimentação com embriōes: "No que se refere à experimentação, e pressupondo a distinção geral entre aquela com propósitos que não sejam diretamente terapêuticos e aquela que é claramente terapêutica para o próprio sujeito, no caso em tela deve-se distinguir também entre a experimentação realizada em embriōes que ainda estão vivos e a experimentação realizada em embriões mortos. Se eles estão vivos, viáveis ou não, devem ser respeitados como todas as pessoas humanas; a experimentação não diretamente terapêutica é ilícita."

63 Eça de Queiroz, A correspondência de Fradique Mendes, 1900 (data da 1". ed.), p. 11: "Todo culto sincero, porém, tem uma beleza essencial, independente dos merecimentos do Deus para quem se evola".

64 Dicionário Houaiss, 2001: “diz-se de ou o ser humano já concebido, cujo nascimento é dado como certo". Novo dicionário Aurélio, 1986: “o ser humano já concebido, cujo nascimento se espera como fato futuro certo". 
volvimento no útero da mãe ${ }^{65}$. Note-se que o novo Código Civil, embora tenha sido promulgado em 2002 , resultou de projeto de lei que foi discutido em um período no qual não era possível separar o embrião do corpo da mulher. Esta possibilidade só surgiu quando do advento da técnica da fertilização in vitro. Aparentemente, circunstâncias da tramitação legislativa do projeto já não permitiram reabrir o texto para tratamento específico do ponto.

Como consequiência das premissas assentadas acima, o embrião resultante da fertilização in vitro, conservado em laboratório: a) não é uma pessoa, haja vista não ter nascido; b) não é tampouco um nascituro, em razão de não haver sido transferido para o útero materno. As normas e categorias tradicionais do direito civil não se aplicam à fecundação extracorporal. Vale dizer: até o advento da Lei $n^{\circ} 11.105 / 2005$, não havia qualquer disciplina jurídica específica para esta entidade: embrião produzido em laboratório, mediante processo de reprodução assistida ${ }^{66}$. Foi precisamente a lei aqui impugnada que instituiu normas limitadoras das pesquisas genéticas e protetivas do embrião.

Em suma: embrião resultante de fertilização in vitro, sem haver sido transferido para o útero materno, não é nem pessoa nem nascituro.

$\mathrm{O}$ argumento que se vem de expor decorre natural e logicamente do Direito vigente no país, pelo menos desde o Código Civil de 1916. E, no plano filosófico, ele só é incompatível com uma única das posições expostas anteriormente a propósito do início da vida: a que crê que ela exista desde o primeiro momento da fecundação. $\mathrm{E}$, no caso presente, com um elemento a mais: o de considerar indiferente que a fecundação tenha sido extra-corporal e que o embrião não terha sido sequer transferido para o útero materno. Com as demais concepções acerca do início da vida, a tese aqui desenvolvida convive em plena harmonia.

De fato, os embriões só podem ser congelados (i) no estágio do zigoto unicelular, (ii) clivados ( 2 a 8 células) ou (iii) em blastocisto (a partir do $5^{\circ}$ dia do desenvolvimento in vitro $)^{67}$ e nunca depois do $14^{\circ}$ dia $^{68}$. Vale dizer: a extração das células-tronco

65 Sílvio Rodrigues, Direito civil, 2001, p. 36: “Nascituro é o ser já concebido, mas que ainda se encontra no ventre materno". V. tb. Maria Helena Diniz, Dicionário jurídico, 1998, p. 334; Plácido e Silva, Vocabulário jurídico, 2004, p. 942 (edição revista e atualizada por Nagib Slaibi Filho).

66 Heloísa Helena Barboza, Proteção jurídica do embrião humano. In: Carlos Maria Romeo Casabona e Juliane Fernandes Queiroz, Biotecnologia e suas implicações ético-jurídicas, 2005, pp. 249 e 257: "Havendo fertilização in vitro, distingue-se, nestes termos, o embrião do nascituro, entendendo-se esse último como o ser já em gestação que, ao que se sabe até a presente data, só pode ocorrer no útero da mulher. (...) Por conseguinte, não há atualmente no Direito brasileiro (este texto é anterior à Lei $n^{\circ} 11.105 / 2005$ ), disciplina legal quanto ao embrião humano, na medida em que, pelas razões expostas, tanto o Código Civil de 1916, quanto o de 2002, contém dispositivos que parecem aplicáveis apenas ao nascituro, ou seja, ao ser concebido e já em gestação no útero de uma mulher".

67 Raquel de Lima Leite Soares Alvarenga, Considerações sobre o congelamento de embriōes. In: Carlos Maria Romeo Casabona e Juliane Fernandes Queiroz, Biotecnologia e suas implicações ético-jurídicas, 2005, p. 241.

68 A partir daí as células, antes multipotentes, começam a se diferenciar e a se converter em 
ocorre ( $i$ ) antes do início da formação do sistema nervoso, quando o embrião é apenas um conjunto de células não diferenciadas; (ii) antes da nidação, i.e., da fixação do embrião no útero; (iii) antes de qualquer viabilidade de vida extra-uterina e, até mesmo, antes que se possa considerá-lo um ser individualizado ${ }^{69}$.

A equiparação do embrião a um ser humano, em sua totalidade corporal e espiritual, não é compatível com o direito brasileiro que já se encontrava em vigor antes mesmo da Lei de Biossegurança. A Lei de Transplante de Órgãos, por exemplo, somente autoriza o procedimento respectivo após o diagnóstico de morte encefálica, momento a partir do qual cessa a atividade nervosa ${ }^{70}$. Se a vida humana se extingue, para a legislação vigente, quando o sistema nervoso pára de funcionar, o início da vida teria lugar apenas quando este se formasse, ou, pelo menos, começasse a se formar. E isso ocorre por volta do $14^{\circ}$ dia após a fecundação, com a formação da chamada "placa neural" 71 . Essa foi, também, a posição adotada pelo Tribunal Constitucional Federal alemão ${ }^{72}$.

oligopotentes, dando causa à formação da placa neural e de outros tecidos.

69 A embriologia tem, por vezes, caracterizado esse estágio de desenvolvimento com a expressão "pré-embrião". Cuida-se de termo cunhado em meados dos anos 1980 para designar o período que compreende as etapas estabelecidas entre a fecundação e os 14 (quatorze) primeiros dias de gestação. O que leva a que não se use a palavra "embrião" ? Enumeram-se quatro razões para isso: (i) durante esse período, o ser não é capaz de sentir prazer ou dor, devido ao fato de não se ter formado, ainda, o sistema nervoso central: (ii) é altíssimo o número de insucessos no desenvolvimento embrionário, normalmente pela dificuldade de fixação no útero; (iii) até os 14 (quatorze) dias ainda é possível que se dividam as células em dọis grupos, formando gêmeos - uma identidade do embrião, portanto, como algo único e singular só poderia ser afirmada depois desse período; (iv) a implantação do embrião no útero somente se completa por volta do $13^{\circ}$ dia de gestação, quando, então, passa a possuir o potencial de se tornar uma pessoa. V. Tania Salem. As novas tecnologias reprodutivas: O estatuto do embrião e a noção de pessoa. Mana 3(1):81-3, 1997.

70 Lei $n^{\circ}$ 9.434/97: "Art. $3^{\circ}$. A retirada post mortem de tecidos, órgãos ou partes do corpo humano destinados a transplante ou tratamento deverá ser precedida de diagnóstico de morte encefálica, constatada e registrada por dois médicos não participantes das equipes de remoção e transplante, mediante a utilização de critérios clínicos e tecnológicos definidos por resolução do Conselho Federal de Medicina."

71 Keith L. Moore, T. V. N. Persaud, Embriologia clínica, 1994, p. 357: "O sistema nervoso desenvolve-se a partir de uma área espessada (...) do ectoderma embrionário, denominada placa neural, que aparece na terceira semana". No mesmo sentido, de acordo com Conselho Federal de Medicina, "um pré-embrião em estágio de oito células sem desenvolvimento da placa neural não pode ser considerado um ser humano. É uma expectativa potencial de vida. Assim como são expectativas de vida os gametas masculinos e femininos, isoladamente" (CFM. Processo Consulta $n^{\circ}$ 1698/96, Rel. Cons. Antônio Henrique Pedrosa Neto, aprovado na Sessão Plenária do dia 11. set.1996).

72 V. BverGE 39:I, 1995: "Vida, no sentido de existência em desenvolvimento de um indivíduo humano, começa, de acordo com reconhecidas descobertas biológico-fisiológicas, no décimo-quarto dia depois da concepção (implantação, individualização). O processo de desenvolvimento que então tem início é contínuo, não se manifestando uma clara definição, nem se permitindo qualquer delimitação precisa entre as várias fases de desenvolvimento da vida humana" (In: Donald P. Kommers, The constitutional jurisprudence of the Federal Republic of Germany, 1997, p. 337). 


\section{VI.3. Inexistência de violação à dignidade da pessoa humana}

Não sendo o embrião uma pessoa, não há que se falar, a rigor, em dignidade humana (CF, art. $1^{\circ}$, III). Não se deve desprezar, todavia, o fato de se tratar de um ser humano em potencial. $\mathrm{E}$ muito embora possa permanecer indefinidamente como uma mera potencialidade, não deve ser instrumentalizado ${ }^{73}$. $\mathrm{O}$ tratamento dado à matéria pela Lei $n^{\circ} 11.105 / 2005$ supera, sem margem de controvérsia, esta objeção, haja vista que somente permite a utilização de embriões fecundados in vitro para fins reprodutivos e que não têm a possibilidade de se tornarem seres humanos, porque inviáveis ou não utilizados no processo de fertilização.

De fato, a noção de potencialidade se traduz como a qualidade do que aiıda não é, mas que pode vir a ser, dadas determinadas condições. Tais condições podem ser internas ou externas. No caso, as condições internas são as características próprias do embrião, a sua constituição genética; as externas são as relativas à implantação em um útero preparado para recebê- $-o^{74}$. A lei brasileira garante que apenas os embriões que não exibam esse potencial sejam utilizados em pesquisas. De fato, de

73 Heloísa Helena Barboza, Proteção jurídica do embrião humano. In: Carlos Maria Romeo Casabona e Juliane Fernandes Queiroz, Biotecnologia e suas implicações ético-jurídicas, 2005, pp. 266 e 268: "Por outro lado, se é certo que o concebido não é 'coisa', atribuir ao embrião pré-implantatório natureza de pessoa ou personalidade seria uma demasia, visto que poderá permanecer indefinidamente como uma potencialidade. (...) No momento, parece que o mais razoável, à luz do princípio da dignidade da pessoa humana, seja conferir ao embriāo humano uma 'tutela particular', desvinculada dos conceitos existentes, mas que impeça, de modo eficaz, sua instrumentalização, dando-lhe, enfim, proteção jurídica condizente, se não com a condição de indivíduo pertencente à espécie humana, com o respeito devido a um ser que não pode ser coisificado". No mesmo sentido, Antonio Junqueira de Azevedo, Caracterização da dignidade da pessoa humana, $R T$ 707: 11, 2002, p. 21: “[D]o embrião pré-implantatório, resultante de processos de fecundação assistida, ou até mesmo de clonagem, constituído artificialmente e que ainda está fora do ventre materno, por não estar integrado no fluxo vital contínuo da natureza humana, é difícil dizer que se trata de 'pessoa humana'. É verdade que, por se tratar da vida em geral e especialmente da vida humana potencial, nenhuma atividade gratuitamente destruidora é moralmente admissível, mas, no nosso entendimento, aí já não se trata do princípio da intangibilidade da vida humana; trata-se da proteção, menos forte, à vida em geral. Dentro desses parâmetros, isto é, sob o ângulo da intangibilidade da vida humana, a própria clonagem terapêutica, como admitida pelo Parlamento Europeu e pelo governo inglês, não é condenável do ponto de vista ético e jurídico".

74 V. Katrien Devolder, Human embryonic stem cell research: why the discardedereated-distinction cannot be based on the potentiality argument, Bioethics 19(2):167, 2005, p. 176-177: "O único ponto sobre o qual todos concordam no que se refere ao sentido de 'potencialidade' é que algo que é potencial não é real, mas pode se tornar real sob certas condições. Essas condiçð̃es podem depender de fatores internos e externos. Em relação ao 'embrião como pessoa em potencial', os fatores internos são as características do próprio embrião (e.g. sua constituição genética, seu potencial de desenvolvimento). Os fatores externos podem estar tanto na gênese do embrião (e.g. aplicação de SCNT) quanto além (e.g. ser escolhido para implantação no útero, ser um embrião excedente, ser abortado). As condições externas, relativas às intenções das pessoas, podem depender de condiçðes internas (selecionamos um embrião porque ele tem características que o colocam como mais 'saudável' do que um outro), mas não necessariamente o fazem (podem basear-se em outras intençð̃es, e.g. uma mulher que não quer um filho)." 
acordo com o inciso I do art. $5^{\circ}$, podem ser utilizadas as células oriundas de "embriōes inviáveis", ou seja, de embriões que não poderiam ser implantados no útero por não apresentarem as condições internas necessárias ao seu desenvolvimento posterior.

Já de acordo com o inciso II, poderão ainda ser usados embriões com três anos ou mais de congelamento. Observe-se que os embriões congelados são aqueles que não foram implantados no útero materno ${ }^{75}$. São embriões que não puderam ser utilizados no tratamento reprodutivo; que foram congelados para garantir que, tendo o tratamento anterior falhado, pudessem vir a ser implantados; e que foram doados para a pesquisa por seus genitores. Não possuem, portanto, as condições externas: são embriões que nunca serão implantados, que não chegarão à nidação e ao desenvolvimento posterior.

A Lei de Biossegurança permite, "para fins de pesquisa e terapia, a utilização de células-tronco embrionárias obtidas de embriōes humanos produzidos por fertilização in vitro". Observe-se que as células-tronco devem ser extraídas de embriões oriundos de tratamento reprodutivo (art. $5^{\circ}$, caput, da Lei n. 11.105/2005). A lei brasileira não permite que sejam utilizadas células-tronco extraídas de embriões produzidos exclusivamente para pesquisas ${ }^{76}$.

Esse requisito tem uma conseqüência ético-jurídica importante: afastar a objeção antiutilitarista, apoiada no núcleo essencial do princípio da dignidade humana, segundo a qual a utilização de embriões em pesquisas significaria tratá-los como meios para a realização das finalidades de outrem ${ }^{77}$. De fato, somente podem ser utilizados em pesquisas os embriões que foram produzidos com o objetivo de serem implantados em um útero materno e de se tornarem, no futuro, seres humanos ${ }^{78}$. Original-

75 Relembre-se, como já assinalado, que a técnica de fertilização in vitro produz um número de embriões maior do que o que pode ser efetivamente implantado no útero materno. Feita a fecundação, o médico seleciona, então, os embriōes que possuem as características necessárias ao posterior desenvolvimento do feto. Os embriōes não implantados são então congelados em condições criogênicas para o caso de a tentativa anterior de implantação não prosperar.

76 No tocante a esse aspecto, a legislação brasileira segue a tendência internacional. Dos países que permitem pesquisas com células-tronco, o Reino Unido é a exceção que merece nota, por permitir também pesquisas com embriões criados apenas com a finalidade de serem utilizados em pesquisas.

77 Trata-se de um conceito de dignidade humana inspirado em uma das formulações do imperativo categórico kantiano, pela qual cada indivíduo deve ser tratado como um fím em si mesmo, e não como um meio para realização de metas coletivas ou de outras metas individuais. Sobre o conceito de dignidade da pessoa humana, v. Ana Paula de Barcellos, A eficácia jurídica dos principios constitucionais. $O$ princípio da dignidade da pessoa humana, 2001; Ingo Wolfgang Sarlet, Dignidade da pessoa humana e direitos fundamentais na Constituição Federal de 1988, 2002; Maria Celina Bodin de Moraes, Danos à pessoa humana, 2002. Sobre a relação do princípio com o debate sobre a possibilidade de pesquisas com células-tronco embrionárias, v. Fuat S. Oduncu, Stem cell research in Germany: Ethics of healing vs. human dignity, Medicine, Health Care and Philosophy $6: 12,2003$.

78 O Conselho Federal de Medicina esclarece, em parecer, como se dá esse processo de reprodução assistida: (a) estimula-se quimicamente a ovulação e, então, colhe-se número indeterminado de 
mente, a finalidade perseguida era a reprodução. Contudo, como a implantação não ocorreu, não há razões para que suas células não sejam utilizadas para promover a vida e a saúde de pessoas que sofrem de graves patologias ${ }^{79}$.

Além disso, de acordo com o $\$ 2^{\circ}$, as "Instituições de pesquisa e serviços de saúde que realizem pesquisa ou terapia com células-tronco embrionárias humanas deverão submeter seus projetos à apreciação e aprovação dos respectivos comitês de ética em pesquisa". Trata-se de dispositivo que garante que as células não sejam utilizadas de forma irresponsável ou caprichosa. Ainda que sejam cumpridos todos os requisitos legais acima enumerados, ou seja, ainda que se trate de embrião inviável ou congelado há mais de três anos, e ainda que os genitores tenham proferido a autorização, a aprovação do comitê de ética da respectiva instituição será exigida, para zelar por uma prática de pesquisa ética e consequiente ${ }^{80}$.

Note-se, por fim, que uma adesão estrita à tese da inconstitucionalidade da pesquisa com células-tronco implicaria também negar a possibilidade da própria fertilização in vitro, a não ser que se sustentasse a necessidade de que todos os embriões fecundados fossem implantados, o que não é possível ${ }^{81}$. Contudo, mesmo

óvulos; (b) estes, em contato com espermatozóides, são fertilizados e se desenvolvem in vitro até o momento em que possuem 8 (oito) células; $(c)$ nesta etapa, selecionam-se os pré-embriőes que serāo levados ao útero; os restantes, são criopreservados (de acordo com a Resolução CFM n. 1.358/92). A criopreservação, conforme salienta o Conselho, tem o objetivo de permitir, "em caso de insucesso ou desejo de nova gravidez, novas tentativas de transferência sem necessidade de novos procedimentos de indução ovulatória, coleta de óvulos e nova fertilização in vitro". (CFM, Processo Consulta n. ${ }^{\circ}$ 1698/96, Rel. Cons. Antônio Henrique Pedrosa Neto, aprovado na Sessão Plenária do dia 11.set.1996). Fica patente, portanto, a finalidade a que serve a preservação por processo criogênico: a reprodução.

79 No entanto, de acordo com o $\$ 1^{\circ}$ do citado artigo, para que o embrião possa ser utilizado, é ainda necessário o consentimento dos genitores. Se os genitores, por razð̃es de consciência, consideram que o embrião que produziram não deva fornecer células para a realização de pesquisas, podem não autorizar o seu uso. A Lei lhes garante essa possibilidade, demonstrando respeito e consideração pelo credo religioso ou filosb́fico por eles professado.

80 Os comitês de ética em pesquisa (CEPs) estão regulados pela Resolução n 196/96 do Conselho Nacional de Saúde. De acordo com a Resolução, "Toda pesquisa envolvendo seres humanos deverá ser submetida à apreciação de um Comitê de Ética em Pesquisa" (art. VII, caput), razão pela qual "as instituiçð̄es nas quais se realizem pesquisas envolvendo seres humanos deverão constituir um ou mais de um Comitê de Ética em Pesquisa (...)". (VII.1). Cada comitê será formado "por colegiado com número não inferior a 7 (sete) membros", devendo sua constituição "incluir a participação de profissionais da área de saúde, das ciências exatas, sociais e humanas, incluindo, por exemplo, juristas, teólogos, sociólogos, filósofos, bioeticistas e, pelo menos, um membro da sociedade representando os usuários da instituição". (VII.4). A Resolução 196/96 (art. VII.13) estabelece ainda quais são as atribuições do CEP. Sobre a constituição, o funcionamento e as atribuiçōes dos comitês de ética em pesquisa no Brasil, v. Corina Bontempo Duca de Freitas, Os comitês de ética em pesquisa: evolução e regulamentação, Bioética 6 (2), 1998; Ellen Hardy; Silvana Ferreira Bento; Maria José Duarte Osis; Eliana Maria Hebling, Comitês de Ética em Pesquisa: adequação à Resolução 196/96, Rev. Assoc. Med. Bras. 50 (4), 2004.

81 V. Deryck Beyleveld; Shaun D. Pattison, Embryo research in the UK: is harmonization in the EU needed or possible? In: Minou Bernadette Friele (ed.), Embryo experimentation in Europe: bio-medical, legal and philosophical aspects, 2001, p. 67. Há ainda quem seja contrário à fertilização 
aqueles que são contra a própria fecundação in vitro ainda têm boas razões para apoiar a possibilidade das pesquisas com células-tronco dos embriões já produzidos: se os embriões não virão, de qualquer forma, a se tornar seres humanos, não haveria por que deixar de atribuir à sua curta existência um sentido nobre, que é o de promover a vida e a saúde de outras pessoas ${ }^{82}$.

\section{Parte IV \\ A QUESTÃO DO PONTO DE VISTA INSTITUCIONAL}

\section{Centralidade da Constituição e constitucionalização do Direito}

O direito constitucional, no mundo em geral e no Brasil em particular, vive um momento de virtuosa ascensão teórica e institucional. O reconhecimento de força normativa à Constituição, a expansão da jurisdição constitucional e o desenvolvimento de uma nova dogmática pós-positivista de interpretação constitucional alçaram a Constituição para o centro do sistema jurídico. Ali passou ela a desfrutar, não apenas da supremacia formal que sempre teve, mas também, e sobretudo, de uma supremacia material, axiológica, potencializada pela abertura de suas normas e pela normatividade dos princípios.

A Constituição passa a ser, assim, não apenas um sistema em si - com a sua ordem, unidade e harmonia - mas também um modo de olhar e interpretar todos os demais ramos do Direito. Este fenômeno, identificado por alguns autores como filtragem constitucional, consiste em que toda a ordem jurídica deve ser lida e apreendida sob a lente da Constituição, de modo a realizar os valores nela consagrados. A constitucionalização do direito infraconstitucional não identifica apenas a inclusão na Lei Maior de normas próprias de outros domínios, mas, sobretudo, a reinterpretação de seus institutos sob uma ótica constitucional ${ }^{83}$.

in vitro mesmo se todos os embriões fertilizados fossem implantados. Essa é a posição defendida pela Congregazione per la Dottrina della Fede. In: Il rispetto della vita umana nascente e la dignità della procreazione, 1987.

82 Sobre a questão da vedação do desperdício [avoidance of waste], v. Katrien Devolder, Human embryonic stem cell research: why the discardedcreated-distinction cannot be based on the potentiality argument, Bioethics $19(2): 167,2005$, p. 173, em passagem na qual resume a posição do governo americano relativamente a esse ponto: "Se estes [embriões excedentes congelados] serão destruídos de qualquer forma, não deveriam ser usados para um bem maior, para pesquisas que têm o potencial de salvar e melhorar outras vidas?' Muitos argumentam que gerar embriões excedentes é um 'efeito colateral' do processo procriativo e que deveríamos permitir que casais os doassem para bons propósitos em vez de jogar fora o seu potencial. Isso não altera a sua disposição final. A idéia subjacente é que, sendo coisas iguais, é melhor fazer algo de bom do que não fazer nada de bom, e que, por conseguinte, deve ser melhor fazer bom uso de algo do que permitir que seja descartado [wasted]".

83 J. J. Gomes Canotilho e Vital Moreira, Fundamentos da Constituição, 1991, p. 45: "A principal manifestação da preeminência normativa da Constituição consiste em que toda a ordem jurídica 
À luz de tais premissas, toda interpretação jurídica é também interpretação constitucional. Qualquer operação de realização do direito envolve a aplicação direta ou indireta da Constituição. Direta, quando uma pretensão se fundar em uma norma constitucional; e indireta quando se fundar em uma norma infraconstitucional, por duas razões: a) antes de aplicar a norma, o intérprete deverá verificar se ela é compatível com a Constituição, porque, se não for, não poderá fazê-la incidir; e b) ao aplicar a norma, deverá orientar seu sentido e alcance à realização dos fins constitucionais.

Em suma: a Constituição figura hoje no centro do sistema jurídico, de onde irradia sua força normativa, dotada de supremacia formal e material. Funciona, assim, não apenas como parâmetro de validade para a ordem infraconstitucional, mas também como vetor de interpretação de todas as normas do sistema.

\section{A jurisdição constitucional e sua legitimidade democrática}

Em sentido amplo, a jurisdição constitucional envolve a interpretação e aplicação da Constituição, tendo como uma de suas principais expressões o controle de constitucionalidade das leis e atos normativos. No Brasil, esta possibilidade vem desde a primeira Constituição republicana (controle incidental e difuso), tendo sido ampliada após a Emenda Constitucional $n^{\circ} 16 / 65$ (controle principal e concentrado). A existência de fundamento normativo expresso, aliada a outras circunstâncias, adiou o debate no país acerca da legitimidade do desempenho pela corte constitucional de um papel normalmente referido como contra-majoritário ${ }^{84}$ : órgãos e agentes públicos não eleitos têm o poder de afastar ou conformar leis elaboradas por representantes escolhidos pela vontade popular.

Ao longo dos últimos dois séculos, impuseram-se doutrinariamente duas grandes linhas de justificação desse papel das supremas cortes/tribunais constitucionais. A primeira, mais tradicional, assenta raízes na soberania popular e na separação de Poderes: a Constituição, expressão maior da vontade do povo, deve prevalecer sobre as leis, manifestações das maiorias parlamentares. Cabe assim ao Judiciário, no desempenho de sua função de aplicar o Direito, afirmar tal supremacia, negando validade à lei inconstitucional. A segunda, que lida com a realidade mais complexa da nova interpretação jurídica ${ }^{85}$, procura legitimar o desempenho do controle de

deve ser lida à luz dela e passada pelo seu crivo". V. também, Paulo Ricardo Schier, Filtragem constitucional, 1999.

84 A expressão "dificuldade contra-majoritária" (the counter-majoritarian difficulty) foi cunhada por Alexander Bickel, The least dangerous branch, 1986, p. 16, cuja $1^{\text {a }}$. edição é de 1962.

85 Relembre-se que no atual estágio da dogmática jurídica reconhece-se que, em múltiplas situações, o juiz não é apenas "a boca que pronuncia as palavras da lei", na expressão de Montesquieu. Hipóteses há em que o intérprete é co-participante do processo de criação do Direito, integrando o conteúdo da norma com valorações próprias e escolhas fundamentadas, notadamente quando se trate da aplicação de cláusulas gerais e princípios. Sobre o tema, v. Luís Roberto Barroso e Ana Paula de Barcellos, O começo da história. A nova interpretação constitucional e o papel dos princípios no direito brasileiro, Revista Forense 371:175. 
constitucionalidade em outro fundamento: a preservação das condições essenciais de funcionamento do Estado democrático. Ao juiz constitucional cabe assegurar determinados valores substantivos e a observância dos procedimentos adequados de participação e deliberação $0^{86}$.

O debate, na sua essência, é universal e gravita em torno das tensões e superposições entre constitucionalismo e democracia. O papel do Judiciário e, especialmente, das cortes constitucionais e supremos tribunais deve ser o de resguardar o processo democrático e promover os valores constitucionais, superando o deficit de legitimidade dos demais Poderes, quando seja o caso. Sem, contudo, desqualificar sua própria atuação, o que ocorrerá se atuar abusivamente, exercendo preferências políticas em lugar de realizar os princípios constitucionais ${ }^{87}$.

É na confluência desses valores que se colocam os dois temas aqui debatidos. Em relação à anencefalia, cuida-se de determinar o espaço legítimo de atuação do Supremo Tribunal Federal na aplicação direta e imediata da Constituição, em situações nas quais não houve manifestação expressa do legislador. No tocante às pesquisas com células-tronco, coloca-se a questão oposta: demarcar os limites legítimos da atuação do Supremo Tribunal Federal nas hipóteses em que houve manifestação expressa do legislador, tendo por objeto matéria que provoca profundo desacordo moral na sociedade.

\section{A ADPF $n^{\circ} 54$ e a questão da atuação do Supremo Tribunal Federal como legislador positivo}

Como visto, não é controvertida a possibilidade de o Judiciário declarar a inconstitucionalidade de uma lei. De outra parte, na linha do conhecimento convencional, a ele não caberia inovar na ordem jurídica, agindo como legislador positivo e criando comando até então inexistente. Em outras palavras: o Judiciário estaria

86 Sobre o tema, vejam-se Cláudio Pereira de Souza Neto, Jurisdição, democracia e racionalidade prática, 2002; José Adércio Leite Sampaio, A Constituiçāo reinventada pela jurisdição constitucional, 2002; Bianca Stamato, Jurisdição constitucional, 2005.

87 Luís Roberto Barroso, Disciplina legal dos direitos do acionista minoritário e do preferencialista. Constituição e espaços de atuação legítima do Legislativo e do Judiciário. In: Temas de direito constitucional, t. III, 2005, p. 314-5: "Como já referido, porém, a Constituição não ocupa, nem pode pretender ocupar todos os espaços jurídicos dentro do Estado, sob pena de asfixiar o exercício democrático dos povos em cada momento histórico. Respeitadas as regras constitucionais e dentro do espaço de sentido possível dos princípios constitucionais, o Legislativo está livre para fazer as escolhas que lhe pareçam melhores e mais consistentes com os anseios da população que o elegeu. A disputa política entre diferentes visozes alternativas e plausíveis acerca de como dar desenvolvimento concreto a um princípio constitucional é própria do pluralismo democrático. $A$ absorção institucional dos conflitos pelas diversas instâncias de mediação, com a consequente superação da força bruta, dá o toque de civilidade ao modelo. Mas não é possível pretender derrotar a vontade majoritária, em espaço no qual ela deva prevalecer, pela via oblíqua de uma interpretação jurídica sem lastro constitucional. Ao agir assim, o intérprete estaria usurpando tanto o papel do constituinte quanto do legislador". 
autorizado a invalidar um ato do Legislativo - agindo como legislador negativo -, mas não a substituí-lo por um ato de vontade própria ${ }^{88}$. A grande questão teórica em discussão na ADPF $n^{\circ} 54$ era a de saber se, ao declarar a não incidência do Código Penal a uma determinada situação, porque isso provocaria um resultado inconstitucional, estaria o STF interpretando a Constituição - que é o seu papel ou criando uma nova hipótese de não punibilidade do aborto, em invasão da competência do legislador ${ }^{89}$.

Como se sabe, o Tribunal, por maioria, conheceu da ação, reconhecendo tratar-se de uma questão de interpretação constitucional e não de criação de Direito novo. É bem de ver, no entanto, que as modernas técnicas de interpretação constitucional como é o caso da interpretação conforme a Constituição - não subvertem o pressuposto de que as decisões judiciais devem ser sempre reconduzidas ao sistema jurídico, a uma norma legal ou constitucional que lhe sirva de fundamento. Mas reconhecem, todavia, a existência de um fenômeno inexorável: a interpretação jurídica dificilmente é unívoca, seja porque um mesmo enunciado, ao incidir sobre diferentes circunstâncias de fato, pode produzir normas diversas ${ }^{90}$, seja porque, mesmo em tese, um enunciado pode admitir várias interpretações, em razão da polissemia de seus termos.

A interpretação conforme a Constituição, portanto, pode envolver (i) uma singela determinação de sentido da norma, (ii) sua não incidência a uma determinada situação de fato ou (iii) a exclusão, por inconstitucional, de uma das normas que podem ser extraídas do texto. Em qualquer dos casos, não há declaração de incons-

88 Nesse sentido, v. STF, DJU 15 abr. 1988, Rp 1.417-DF, Rel. Min. Moreira Alves: "Ao declarar a inconstitucionalidade de uma lei em tese, o STF - em sua função de Corte Constitucional - atua como legislador negativo, mas não tem o poder de agir como legislador positivo, para criar norma jurídica diversa da instituída pelo Poder Legislativo". O tipo de preocupação subjacente à terminologia legislador positivo, que remonta ao debate entre Kelsen e Carl Schmitt a propósito de quem deveria ser o guardião da Constituição, tem sido amplamente revisitado pela moderna teoria constitucional. V. a propósito, Bianca Stamato Fernandes, Jurisdição constitucional, 2004, p. 97. 89 STF, ADPF $n^{\circ}$ 54, Rel. Min. Marco Aurélio. Por 7 votos a 4, o STF decidiu conhecer da ação e apreciar-lhe o mérito.

90 A doutrina mais moderna tem traçado uma distinção entre enunciado normativo e norma, baseada na premissa de que não há interpretação em abstrato. Enunciado normativo é o texto, o relato contido no dispositivo constitucional ou legal. Norma, por sua vez, é o produto da aplicação do enunciado a uma determinada situação, isto é, a concretização do enunciado. De um mesmo enunciado é possível extrair diversas normas. Por exemplo: do enunciado do art. $5^{\circ}$, LXIII da Constituição - o preso tem direito de permanecer calado - extraem-se normas diversas, inclusive as que asseguram o direito à não auto-incriminação ao interrogado em geral (STF, DJU 14 dez. 2001, HC 80.949, Rel. Min. Sepúlveda Pertence) e até ao depoente em CPI (STF, DJU 16 fev. 2001, HC 79.812, Rel. Min. Celso de Mello). Ş̧-hre o tema, v. Karl Larenz, Metodologia da ciência do direito, 1969, p. 270 e ss.; Friedrich Muller, Métodos de trabalho do direito constitucional, Revista da Faculdade de Direito da UFRGS, Edição especial comemorativa dos 50 anos da Lei Fundamental da República Federal da Alemanha, 1999, p. 45 e ss.; Riccardo Guastini, Distinguendo. Studi di teoria e metateoria del diritto, 1996, p. 82-3; e Humberto Ávila. Teoria dos principios, 2003, p. 13. 
titucionalidade do enunciado normativo, permanecendo a norma no ordenamento. No caso específico aqui tratado, a tese defendida é a de que o Tribunal proceda à interpretação conforme a Constituição das normas do Código Penal que cuidam do aborto, pronunciando sua não incidência à situação em que a gestante de feto anencefálico, por deliberação própria, prefira interromper a gravidez.

\section{A ADIn $n^{\circ} 3.510$ e os limites da atuação do Supremo Tribunal Federal como legislador negativo}

A Constituição de um Estado democrático tem duas funções principais. Em primeiro lugar, compete a ela veicular consensos mínimos, essenciais para a dignidade das pessoas e para o funcionamento do regime democrático, e que não podem ser afetados por maiorias políticas ocasionais (ou exigem para isso um procedimento especialmente complexo). Esses consensos elementares, embora possam variar em função das circunstâncias políticas, sociais e históricas de cada país ${ }^{91}$, envolvem a garantia de direitos fundamentais, a separação e a organização dos poderes constituídos e a fixação de determinados fins de natureza política ou valorativa.

Em segundo lugar, cabe à Constituição garantir o espaço próprio do pluralismo político, assegurando o funcionamento adequado dos mecanismos democráticos. A participação popular, os meios de comunicação social, a opinião pública, as demandas dos grupos de pressão e dos movimentos sociais imprimem à política e à legislação uma dinâmica própria e exigem representatividade e legitimidade corrente do poder. Há um conjunto de decisões que não podem ser subtraídas dos órgãos eleitos pelo povo a cada momento histórico. A Constituição não pode, não deve, nem tem a pretensão de suprimir a deliberação legislativa majoritária ${ }^{92}$.

A jurisdição constituciona!, como visto, tem como uma de suas principais expressões o controle de constitucionalidade. No desempenho desse papel relevante e delicado - inclusive por seu caráter contra-majoritário ${ }^{93}-$, o tribunal constitucional, o Supremo Tribunal Federal, pode declarar a invalidade e paralisar a eficácia de atos normativos que atentem contra a Constituição. Sua missão é a de resguardar o processo democrático e promover os valores constitucionais. No entanto, em nome da legitimidade democrática, tal atuação não pos̉e desbordar para o exercício de preferências políticas, devendo conter-se nos limites da realização dos princípios constitucionais.

91 V. J. J. Gomes Canotilho, Rever ou romper com a Constituição dirigente? Defesa de um constitucionalismo moralmente reflexivo, $R T$-CDCCP 15:7, 1996.

92 No sentido do texto, v. Ana Paula de Barcellos, Ponderação, racionalidade e atividade jurisdicional. 2005.

93 A expressão, cunhada por Alexander Bickel (The least dangerous branch, 1986, p. 16), designa a circunstância de os órgãos do Judiciário, cujos agentes não são eleitos, poderem invalidar atos do Legislativo, cujos agentes são eleitos pelo povo e representam a vontade majoritária. 
A suprema corte atua como intérprete da razão pública, impondo o respeito aos consensos mínimos consubstanciados na Constituição, mas respeitando a deliberação política majoritária legítima ${ }^{94}$. Pois bem: no caso específico, a manifestação do Congresso Nacional, por ocasião da aprovação da Lei no $11.105 / 2005$, foi inequívoca, mediante votação expressiva na Câmara dos Deputados $(85 \%$ dos parlamentares presentes votaram favoravelmente) e no Senado Federal ( 53 votos favoráveis contra $2)^{95}$. O debate na sociedade e nos meios de comunicação tem sido amplo e significativo.

A conclusão que se extrai de todos esses elementos afigura-se simples. A questão em discussão, sobretudo se levada para o plano do momento de início da vida, envolve um profundo desacordo moral na sociedade. Logo, não se está diante de matéria que possa figurar na categoria dos consensos mínimos. Nesse ambiente, o Congresso Nacional, expressando a vontade política majoritária da sociedade, regulou o tema, de uma maneira que respeita o pluralismo político, isto é, a autonomia de cada um. De fato, ao exigir o prévio consentimento dos genitores para a realização de pesquisas com células-tronco, a lei assegurou o direito de cada um agir de acordo com sua ética pessoal.

Por todas as razões expostas, não se justifica nem se legitima a atuação contramajoritária do Supremo Tribunal Federal.

\section{CONCLUSÃO}

Ao fim desse estudo, é possível compendiar suas idéias centrais em duas proposições:

A. À luz da Constituição, as mulheres portadoras de fetos anencefálicos devem ter o direito subjetivo de interromperem a gestação, se assim desejarem. Esta hipótese não configura crime de aborto. Obrigar a mulher a levar a termo uma gravidez inviável, submetendo-a em vão a todas as consequiências físicas e emocionais de

94 O uso da razão pública importa em afastar dogmas religiosos ou ideológicos - cuja validade é aceita apenas pelo grupo dos seus seguidores - e utilizar argumentos que sejam reconhecidos como legítimos por todos os grupos sociais dispostos a um debate franco, ainda que não concordem quanto ao resultado obtido em concreto. $O$ contrário seria privilegiar as op̧̧ões de determinados segmentos sociais em detrimento das de outros, desconsiderando que o pluralismo é não apenas um fato social inegável, mas também um dos fundamentos expressos da República Federativa do Brasil, consagrado no art. $1^{\circ}$, inciso IV, da Constituição. Sobre esta temática, $v$. especialmente a obra de John Rawls, notadamente: Uma teoria de justiça, Liberalismo político e Direito dos povos. $\mathrm{Na}$ literatura nacional, v. Cláudio Pereira de Souza Neto, Teoria constitucional e democracia deliberativa, 2005; e Nythamar de Oliveira, Rawls, 2005.

95 Registre-se aqui a pertinência do parâmetro proposto por Peter Häberle, Hermenêutica constitucional: A sociedade aberta dos intérpretes da Constituição, trad. Gilmar Ferreira Mendes, 1997. segundo o qual quanto mais efetiva for a participação na aprovação da lei, menos intenso deve ser o controle de constitucionalidade. 
uma gestação, viola o princípio da dignidade humana e equipara-se à tortura psicológica.

B. As pesquisas com células-tronco embrionárias oferecem perspectiva de cura para doenças que causam o sofrimento e a morte de milhões de pessoas. A utilização de embriões excedentes do processo de fertilização in vitro não viola o direito à vida nem a dignidade humana. Antes de ser transferido para o útero materno, embrião não é pessoa humana nem nascituro. Nada obstante isso, a legislação em vigor protege a dignidade do embrião, vedando que ele seja produzido apenas para fins de pesquisa, assim impedindo sua funcionalização. $O$ tratamento jurídico dado ao tema pela Lei $\mathrm{n}^{\circ} 11.105 / 2005$ (art. $5^{\circ}$ ) é compatível com o texto constitucional. 